\title{
Cuenca, Poeta de Transición ${ }^{1}$
}

$\mathbf{M}$ UCHA razón asiste a Francisco Monterde en la atracción que profesa particularmente por dos períodos de la literatura mexicana: el prerromanticismo y el premodernismo. Epocas de lenta, secreta traslación de la sensibilidad, de insensible progreso hacia nuevas formas, de abandono de unos modelos para fijar la devoción en otros, de inseguridad que testimonia la inconformidad con los estilos vigentes y la apetencia de otros que poco a poco van integrándose. Los escritores de tales épocas, bisagras de las escuelas literarias, son casi siempre, y Monterde lo sabe muy bien, escritores oscuros y de segunda categoría. Su valor es mucho más histórico que intrínseco. Valen, en suma, más en cuanto se escapan de una escuela y preparan el advenimiento de otra, que por su calidad misma.

Tales estudios, entonces, han de seducir a aquellos investigadores aptos para registrar pacientemente esos secretos pasos que preparan las grandes figuras; a aquellos investigadores, también, que pueden renunciar a la atracción de los nombres consagrados para hundirse en la investigación árida de las figuras de recodo. La educación literaria y la sensibilidad crítica de Monterde - responsable, minuciosa, de segura perspicacia - le inclinan naturalmente a trabajos de esta especie. En 1939, llevó a cabo el estudio de Fray Manuel de Navarrete - y la edición crítica de sus Poesías profanasen quien fijó definitivamente el tránsito del neoclasicismo al romanticismo. Ahora, para cerrar el ciclo, presenta este estudio sobre la poca considerada figura del poeta y prosista Agustín F. Cuenca.

Es por demás encarecer la importancia de tales exploraciones. La historia de la literatura mexicana, si no está por hacerse, apenas ahora se está haciendo. No existía en realidad sino un amplio mate- 
rial erudito forjado en el pasado siglo y unos cuantos intentos, no del todo seguros, para realizar la historia de nuestras letras. La tarea, pues, consiste sobre todo en rectificar juicios precipitados e informaciones erróneas; en alumbrar períodos obscuros e integrar, en fin, la historia crítica de nuestra literatura.

En tal situación, estos estudios de Monterde son preciosos para la investigación de las letras mexicanas, en cuanto dan a Navarrete y a Cuenca, de una vez por todas, su precisa significación literaria y establecen definitivamente el juicio que será preciso adoptar frente a su obra. Ambos participan de las virtudes ya conocidas en los trabajos anteriores de Francisco Monterde: la precisión erudita, el conocimiento exhaustivo de la materia, la sobriedad crítica que le hace colocar a los autores que estudia en el justo plano de su significación, como se ha dicho, más histórica que intrínseca.

La personalidad de Agustín F. Cuenca requería, sin duda, esta revalorización que le ha dedicado Monterde. En su tiempo, interesó por motivos diferentes a aquellos que ahora nos hacen estudiarle. Por otra parte, era Cuenca un poeta a quien la crítica actual había prestado muy escasa atención. Apenas existían fugaces menciones de Nervo, Urbina y de nuestros más recientes historiadores de la literatura mexicana, González Peña y Jiménez Rueda. En 1919, Manuel Toussaint formula una antología del poeta precedida de un importante estudio en el que ya adelanta algunos de los tópicos que luego habrá de estudiar Monterde. Pero, lo que en ese trabajo era sólo alusión, precisaba indudablemente una formulación más detallada y una demostración de lo insinuado. Una revisión, también, de todos los aspectos de la obra de Cuenca, para redimir definitivamente aque1la porción viva o significativa. Tales indispensables trabajos son los que ha realizado Monterde en su reciente ensayo. Cinco capítulos lo integran: El escritor y su época, La biografía olvidada, El drama, Las poesías, y un Apéndice que reproduce un trabajo periodístico, "Entusiasmo prematuro", del autor estudiado.

En el primero, realiza una visión panorámica de los aspectos de Cuenca, que luego ha de estudiar pormenorizadamente, al mismo tiempo que va revisando la actuación de Cuenca en su época como periodista independiente, como biógrafo de Angela Peralta, como poeta en su intimidad y como transitorio dramaturgo. Los juicios de sus contemporáneos sobre su obra periodística y dramática, el estado de 
la poesía en tiempos de Cuenca - reacción realista, primeros pasos del becquerianismo - y la propia evolución de éste, su camino inverso al que un siglo antes siguiera Navarrete, su pudor que lo lleva a ocultar, inéditas, sus composiciones a causa de la inseguridad, que habrá de llevarlo luego a los umbrales del modernismo, quedan establecidos en el presente capítulo que se cierra con los datos biográficos que de su amigo Cuenca ofrece Juan de Dios Peza.

La biografía de Angela Peralta - que se publica en 1873, cuando Cuenca tiene apenas 23 años-, es analizada en segtida con suficiente amplitud para establecer su significación: trabajo de juventud de un escritor aún romántico que tiene "más del entusiasta elogio de un aficionado a la música, admirador de la artista, que de la ponderada apreciación de los méritos de ésta".

Las circunstancias en que se representa la única obra dramática de Agustín F. Cuenca, La cadena de hierro, la descripción del asunto y técnica de la pieza, los juicios que merece del Maestro Altamirano - rectificados prudentemente por Monterde-, el análisis de los retoques que hace a su obra Cuenca, patentizadores de sus preocupaciones estilísticas y de efectos dramáticos, integran el capítulo denominado E1 drama.

En el siguiente se ingresa a la porción más importante del trabajo de Monterde: la investigación en las poesías de Cuenca del tránsito del romanticismo al modernismo que habrá de probar la tesis con que se presenta el trabajo. Luego de fijados los elementos que se han distinguido en su poesía, el erótico y el descriptivo y los particulares matices con que trata y reviste a tales elementos, se pasa a analizar cuidadosamente cada una de las poesías más significativas. Se registran en ellas sus pasos, sus tanteos, las influencias y remembranzas que presentan de poetas de su devoción, sus temas preferidos y sus variaciones, sus mejores momentos y, en suma, cada uno de los rasgos que es preciso notar y fijar para su conocimiento. Con certero y preciso juicio analiza también Monterde la significación de sus predilecciones métricas, y la procedencia de éstas, los refinamientos tímidos pero intencionados de sus innovaciones, su dilección por Góngora - verdaderamente salvadora de su poesía-, su adopción significativa del serventesio español aclimatado en México, sus más perceptibles influencias, Zorrilla y Espronceda. 
Con estos elementos se realiza luego el análisis de la transición - la sutil y avisada operación que requiere la mayor sagacidad para lograr evitar los engaños en materia tan movediza - en donde el investigador se pone a dura prueba. El procedimiento de Monterde en tal coyuntura es el más sensato. Ante todo, precisa fijar los rasgos aceptados por la crítica del modernismo para confrontarlos con los de Cuenca y ver hasta dónde participa de ellos o los anuncia. Así, consigue Monterde descubrir en el poeta que estudia cuando menos una acusadora larva de cada uno de los elementos esenciales del modernismo. Las innovaciones que luego habrán de madurar se encuentran visiblemente en su corta obra, gracias a este delicado análisis. El neologismo y el exotismo, gratos a la manera en 'que florecerá Dario, viven ya en nuestro poeta y le hacen merecedor de figurar como uno de los precursores del movimiento, como un preludio de la música inminente de Gutiérrez Nájera.

Antes de concluir la investigación con un resumen de la significación de Cuenca en cada uno de los géneros literarios que cultivó, traza Monterde otros aspectos de Cuenca que cierran el dibujo de su personalidad: el defensor del pueblo, el amigo y los homenajes póstumos que ha merecido.

La acuciosidad y el rigor de un trabajo como el reseñado, manifiestan ya su importancia para los estudios de la literatura mexicanạ. Fija ciertamente la significación del autor, agota un capítulo, ofrece a los estudiosos de nuestras letras y al conocimiento público la imagen precisa de un interesante personaje olvidado y de una obra especialmente importante; contribuye, en fin, al mejor conocimiento de la historia de nuestra cultura.

José Luts Martinez

1 Francisco Monterde.-Agustín F. Cuenca. El prosista. El Poeta de transición. México, 1942. 140 pp. 